ARAŞTIRMA / RESEARCH

\title{
Should panniculectomy be applied with ventral hernia repair in a single session?
}

Tek seansta ventral herni onarımı ile birlikte pannikülektomi de uygulanmalı mı?

\author{
Serdar Kırmız1 ${ }^{10}$, Emil Hüseyinoğlu2 \\ ${ }^{1}$ Yozgat City Hospital, Gastroenterology Surgery, ${ }^{2}$ General Surgery, Yozgat, Turkey.
}

\section{Cukurova Medical Journal 2021;46(3):959-965.}

\begin{abstract}
Purpose: The aim of this study is to investigate whether simultaneous panniculectomy applications in ventral hernia repair increases postoperative morbidity rates.

Materials and Methods: The study was carried out retrospectively between January 2018 and December 2020. The patients were evaluated in terms of sex, age, body mass index, accompanying diseases, hernia type and size, abdominal surgery history, ASA value (American Society of Anesthesiology), postoperative complications, hospitalization, and follow-up durations. Post-operative complications were evaluated according to the ClavienDindo classification.

Results: It was determined that 14 patients underwent simultaneous panniculectomy and ventral hernia repair (Group 1), while 27 patients underwent sole ventral hernia repair (Group 2). In Group 1, the hernia defect area was approximately 6.25-fold higher. In patients with a panniculectomy, hospitalization time was significantly longer. The median follow-up period was 8.5 months (214) in Group 1, and 14 months in Group 2 (3-36). In multiple linear regression analyses, only the effect hernia defect area was significant on the hospitalization time. There were no significant differences between the groups in terms of complications and hernia recurrence.

Conclusion: Simultaneous panniculectomy applications in ventral hernia repairs do not increase the rate of complications and hernia recurence. A simultaneous panniculectomy application can be applied safely to patients who want to "eliminate" both of their problems in a single session.
\end{abstract}

Keywords:. Ventral hernia, incisional hernia, umbilical hernia, epigastric hernia, panniculectomy.

\section{Öz}

Amaç: Bu çalışmanın amacı, ventral hernide eş zamanlı pannikülektomi uygulamasının postoperatif morbidite oranlarını artırıp artırmadığını araştırmaktır.

Gereç ve Yöntem: Çalışma Ocak 2018- Aralık 2020 tarihleri arasında Yozgat Şehir Hastanesi Genel Cerrahi Servisinde, retrospektif olarak gerçekleştirildi. Hastaların cinsiyet, yaş, vücut kitle indeksi, yandaş hastalıkları, herni tipi ve boyutu, geçirilmiş karın cerrahisi öyküsü, ASA değeri (American Society of Anesthesiology), post-operatif komplikasyonlar, hastane yatış ve takip süreleri değerlendirildi. Post-operatif komplikasyonlar ClavienDindo sınıflamasına göre değerlendirildi.

Bulgular: On dört hastaya eş zamanlı pannikülektomi ve ventral herni onarımı (Grup 1), 27 hastaya sadece ventral herni onarımı (Grup 2) yapıldı. Grup 1'de herni defekti alanı yaklaşık 6,25 kat daha fazlaydı. Hastane yatış süresi pannikülektomi uygulanan hastalarda anlamlı olarak daha uzundu. Ortanca takip süresi Grup 1 hastalarda 8,5 ay (214), diğer grupta 14 aydı (3-36). Çoklu lineer regresyon analizlerinde hastane yatış süresi üzerinde sadece herni defekt alanın anlamlı etkisi olduğu görüldü. En ciddi komplikasyon Clavien-Dindo sınıflamasına göre 3b (genel anestezi altında cerrahi müdahale) grubunda oluşan cilt nekrozuydu. Yara yeri komplikasyon ve herni rekürrensi açısından gruplar arasında anlamlı fark saptanmadı.

Sonuç: Ventral herni onarımların eş zamanlı pannikülektomi uygulaması komplikasyonları ve nüks oranını artırmamaktadır. Her iki probleminden de tek seansta kurtulmak isteyen hastalara güvenle uygulanabilir.

Anahtar kelimeler: Ventral herni, insizyonel herni, umblikal herni, epigastrik herni, pannikülektomi 


\section{INTRODUCTION}

Ventral hernias define the abdominal wall defects except for the groin hernia. Ventral hernias include the middle-line (epigastric, umbilical), lateral (spiegel, lumbar), and incisional hernias. Ventral hernia repair is recommended for the cases to be potentially symptomatic and complicated ${ }^{1}$. In recent years, laparoscopic and robotic surgeries are also an option, however, the open method continues to be a common method of treatment ${ }^{2}$. For an optimal result, a tension-free hernia repair and the placement of mesh that will cover the edges of the defect approximately $4 \mathrm{~cm}$ (onlay, inlay, or sublay) in hernia cases larger than $2 \mathrm{~cm}$ are adopted ${ }^{3}$. Another pathology of the abdominal wall associated with the surgery is the pannus tissue consisting of fat tissue in the skin and sub-skin. It has been known that quality of life is low due to poor aesthetic appearance, selfesteem loss, and hygienic and infectious problems. Therefore, in some cases, panniculectomy becomes inevitable, and satisfactory results can be obtained as a result of the operation ${ }^{4}$. In general surgical practice, in addition to ventral hernia repair, there may be some cases where the patient might want to "eliminate" their pannus. However, the fact that both surgeries are open to wound complications, especially in the place of wound, surgeons may hesitate for the procedure $^{5}$. Despite these concerns, performing these two procedures in a single session has advantages including a better surgical exposure in terms of the defect repair, the excision of a relatively poor circulation tissue, and a less stressful hernia repair ${ }^{6}$. In the literature, the advantages and disadvantages of this procedure have been discussed ${ }^{6-}$ ${ }^{8}$. The present study investigated postoperative morbidities in patients that underwent sole ventral hernia repair and simultaneous ventral hernia repair with panniculectomy. It was aimed to contribute to the literature by determining whether it increases rates of post-operative complication and hernia recurence of this simultaneous procedure.

\section{MATERIALS AND METHODS}

The present study was conducted at the Yozgat City Hospital General Surgery Service between January 2018 and December 2020. The study was performed retrospectively. The ethics approval was received from Bozok University Clinical Research and Ethics Assembly (No: 2017-KAEK-189_2021.02.10_12). Electronic patient data was used for the study. The patients who underwent sole ventral hernia repair operations or simultaneous ventral hernia repair and panniculectomy operations in the abovementioned date range were included in the study. Epigastric, umbilical and incisional hernias were defined as ventral hernias?. Panniculectomy was defined as the excision of the redundant portion in the fat tissue in the skin or sub-skin on the abdominal wall. Patients with simultaneous ventral hernia repair and panniculectomy were assigned to Group 1, while those who underwent sole ventral hernia repair were assigned to Group 2. Cases under 18 years of age and with emergency indications were excluded from the study. The patients were evaluated in terms of sex, age, body mass index (BMI), accompanying diseases, hernia type and size, abdominal surgery history, ASA value (American Society of Anesthesiology), postoperative complications, hospitalization, and follow-up durations. Hernia defect size was obtained by multiplication of intraoperative widest horizontal and vertical measures $(\mathrm{cm})$ and expressed as " $\mathrm{cm}^{2}$ "' . In multiple hernia cases, the guideline by the European Hernia Association was taken as a reference to determine the defect size ${ }^{9}$.

\section{Surgical technique}

Panniculectomy: This operation was performed by the same technique by a single surgeon. It was seen that the incision area was drawn in the standing position on all the patients that will undergo panniculectomy. The incision area comprised the pubic hairline at the bottom and spina iliac anterior superior pelvic regions at both sides. The top limit was determined according to the level of the hernia defect, the volume of the pannicus tissue, and the surgeon's decision. Thus, the skin and sub-skin fat tissues were horizontally excised until an optimal result was obtained for the patient.

Hernia repair: It was seen that hernia repairs were carried out by two general surgeons using the same technique. After the hernia sack was excised, the defect was primarily closed using a 1-0 or 2-0 nonabsorbable polypropylene suture (Boz, Ankara, Turkey). In cases where a primary closure could not be performed or the closure was strained, the bilateral component separation method was adopted. In all of the patients in both groups, a polypropylene mesh (Altaylar, Ankara, Turkey) was placed onlay on the defect. Mesh was fixed to subside the hernia defect a minimum of $3-5 \mathrm{~cm}$ with continuous or separate nonabsorbable $2-0$ or 3-0 polypropylene sutures (Boz, Ankara, Turkey). All patients had at least a Jackson 
Pratt drain (4 Medical, Ankara, Turkey) and the drain was removed when the drain output dropped below $30 \mathrm{cc}$.

Post-operative complications were evaluated according to the Clavien-Dindo classification ${ }^{10}$. Post-operative wound complications (abscess, seroma, skin necrosis) and systemic complications (infection, organ failure) were determined. Erythema and purulent discharges at the surgical side were considered as wound infections. Seroma was defined as the collection of liquid in the operation area. Necrosis was defined for the situations developed after ischemia on the skin and sub-skin tissues that required debridement.

\section{Statistical analysis}

The categorical data were shown as figures $(\mathrm{N})$ and percentages $(\%)$ while numerical values were shown as median (range, lower-upper values). Descriptive and comparative statistical analysis was performed using the SPSS-22 (Statistical Package for the Social Sciences, Inc, Chicago, IL, USA) software for statistical analysis. The Mann-Whitney $U$ test was used for the numerical data and the Fisher's Exact Chi-Square test was used for the categorical data. The relationship between the parameters was evaluated with the binary logistics and multiple linear regression analyses. The regression analyses included age, sex, ASA, BMI, hernia defect area, smoking status, and hospitalization time parameters. In the selection of variables placed in the model, clinical and literature data were taken into consideration.

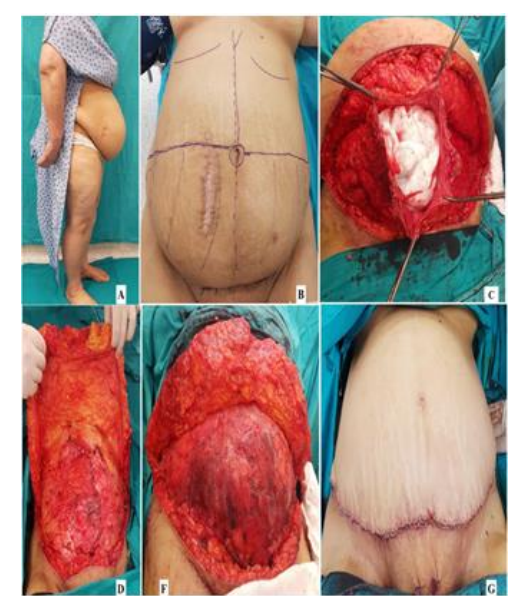

Figure 1. Lateral view of a patient (A), supine position of a patient and skin and subcutaneous adipose tissue to be resected (B), hernia defect $(C)$, primary repair (D), preperitoneal mesh (F), skin closure.

\section{RESULTS}

Fourteen patients underwent simultaneous panniculectomy and ventral hernia repair (Group 1), while 27 patients underwent sole ventral hernia repair operations (Group 2). The demographic characteristics, the operative indications, and the post-operative process of the patients were shown in Table 1.

General anesthesia was applied in all patients. Antibiotic prophylactic antibiotherapy was initiated 30-60 minutes before the operations with 1st generation intravenous (cefazolin). Antibiotic prophylaxis continued for 24 hours. The patients with thromboembolism risk received prophylactic low-molecular-weight heparin postoperatively. No patients had organ failure or mortality.

The most serious complications were the skin necrosis formed in the $3 \mathrm{~b}$ group (surgical intervention under general anesthesia) according to the Clavien-Dindo classification. There were no significant differences between the groups in terms of complications $(28.5 \%$ vs $33.3 \%, p=0.22)$. In wound infections, antibiotherapy was revised in accordance with the suggestions of an Infectious diseases specialist were treated with appropriate antibiotics.

In cases with seroma formations percutaneous aspiration and, where necessary, a drainage tube was placed and the use of tight corsets was recommended. Debridement and vacuum-assisted closure (VAC) was applied under general anesthesia in patients with skin necrosis.

The hernia defect area in Group 1 was approximately 6.25 -fold larger $(p<0.001)$. Hospitalization time was found to be significant in patients with panniculectomy $(p=0.02)$. Comorbidity rates were $57.1 \%(n=8)$ in Group 1 in , and 48.1\% $(n=13)$ in Group 2.

There were no significant differences between the groups according to the ASA scoring $(p=0.72)$. The Group 1 patients were not statistically different despite being relatively young and mostly consisted of women ( $p=0.39, p=0.13$, respectively). The smoking rate in Group 1 patients was $7.1 \%(n=1)$, while it was $22.2 \%(n=6)$ in Group $2(p=0.39)$. Incisional hernia comprised $71.4 \%(n=10)$ of Group 1 while it comprised $74 \%(n=20)$ of the patients in Group $2(p=0.71)$. The median follow-up period was 8.5 months (2-14) in Group 1, and 14 months (3-36) in the other group $(p=0.01)(p=0.01)$. There were no 
significant effects of age, sex, ASA, BMI, hernia defect area, and smoking (Table 2) on the postoperating complication rates (Table 2). In multiple linear regression analyses, only the hernia defect area was significantly effective on the hospitalization time (Table 3).

Table 1. Demographic and perioperative data of all patients.

\begin{tabular}{|c|c|c|c|}
\hline & Group $1(n=14)$ & Group $2(n=27)$ & $p$ \\
\hline Age (years) & $48(40-75)$ & $56(28-78)$ & $0.39 *$ \\
\hline $\operatorname{Sex}(F / M)$ & $13(\% 92.8) / 1(\% 7.1)$ & $19(\% 70.4) / 8(\% 29.2)$ & $0.13^{\#}$ \\
\hline $\mathrm{BMI}\left(\mathrm{kg} / \mathrm{m}^{2}\right)$ & $32(27-41)$ & $33(22-41)$ & $0.59 *$ \\
\hline Hernia defect size $\left(\mathrm{cm}^{2}\right)$ & $225(64-625)$ & $36(9-225)$ & $0.001 *$ \\
\hline ASA score & & & $0.72^{\#}$ \\
\hline ASA 1 & $4(\% 28.6)$ & $9(\% 33.3)$ & \\
\hline ASA 2 & $8(\% 57.1)$ & $10(\% 37)$ & \\
\hline ASA 3 & $2(\% 14.3)$ & $8(\% 29.6)$ & \\
\hline History of smoking $(+/-)$ & $1(\% 7.1) / 13(\% 92.8)$ & $6(\% 22.2) / 21(\% 77.8)$ & $0.39 \#$ \\
\hline Comorbidity (+/ -) & $8(\% 57.1) / 6(\% 42.8)^{\&}$ & $13(\% 48.1) / 14(\% 51.8)^{\& \& \&}$ & $0.74^{\#}$ \\
\hline $\mathrm{HT}$ & $5(\% 50)$ & $11(\% 55)$ & \\
\hline $\mathrm{DM}$ & $3(\% 30)$ & $6(\% 30)$ & \\
\hline COPD & $2(\% 20)$ & $3(\% 15)$ & \\
\hline Pre-operative diagnosis & & & $0.71^{\#}$ \\
\hline Incisional hernia & $10(\% 71.4)$ & $20(\% 74)$ & \\
\hline Epigastric hernia & $2(\% 14.3)$ & $4(\% 14.8)$ & \\
\hline Umbilical hernia & $2(\% 14.3)$ & $3(\% 11.1)$ & \\
\hline Post-operative complications & & & $0.22^{\#}$ \\
\hline Wound infection/abscess & $2(\% 50)$ & $5(\% 50)$ & \\
\hline Seroma & $1(\% 25)$ & $3(\% 30)$ & \\
\hline Skin Necrosis & $1(\% 25)$ & $1(\% 10)$ & \\
\hline LOS (days) & $6(2-38)$ & $2(1-14)$ & $0.02 *$ \\
\hline Follow-up (months) & $8.5(2-14)$ & $14(3-36)$ & $0.01 *$ \\
\hline Hernia recurrence & $2(\% 14.3)$ & $3(\% 11.1)$ & $0.84^{\#}$ \\
\hline
\end{tabular}

AS A American Society of Anesthesiology, BMI body mass index, $H T$ hypertension, $D M$ diabetes mellitus, $C O P H$ chronic obstructive

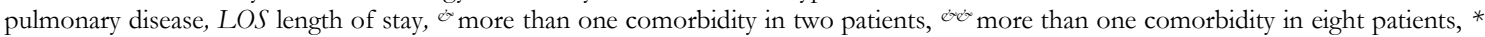
Mann-Whitney U test, \# Fisher's Exact Chi-Square test

Table 2. Effects of demographic parameters on length of hospital stay

\begin{tabular}{|l|c|c|c|c|}
\hline \multirow{2}{*}{} & \multicolumn{3}{c|}{} & \multicolumn{2}{c|}{ 95 \% CI for B } \\
\cline { 2 - 5 } & $\mathbf{B}$ & $\boldsymbol{p}$ & Lower & Upper \\
\hline Age $($ years) & 0.048 & 0.609 & -0.142 & 0.239 \\
\hline Sex & -2.308 & 0.443 & -8.362 & 3.747 \\
\hline ASA & -2.431 & 0.233 & -6.505 & 1.643 \\
\hline BMI $\left(\mathrm{kg} / \mathrm{m}^{2}\right)$ & 0.121 & 0.568 & -0.307 & 0.550 \\
\hline Hernia defect size $\left(\mathrm{cm}^{2}\right)$ & 0.433 & $\mathbf{0 . 0 2 0}$ & 0.073 & 0.793 \\
\hline History of smoking & 2.577 & 0.459 & -4.436 & 9.589 \\
\hline
\end{tabular}

$B$ beta coefficient, $C I$ confidence interval, $A S A$ American Society of Anesthesiology, $B M I$ body mass index

Table 3. Effects of demographic parameters on wound complications.

\begin{tabular}{|l|c|c|c|c|}
\hline & & & \multicolumn{2}{|c|}{ 95 \% CI for OR } \\
\hline & OR & $\boldsymbol{p}$ & Lower & Upper \\
\hline Age (years) & 0.976 & 0.618 & 0.888 & 1.073 \\
\hline Sex & 1.835 & 0.690 & 0.093 & 36.194 \\
\hline ASA & 3.835 & 0.079 & 0.858 & 17.149 \\
\hline BMI $\left(\mathrm{kg} / \mathrm{m}^{2}\right)$ & 1.164 & 0.136 & 0.953 & 1.421 \\
\hline Hernia defect size $\left(\mathrm{cm}^{2}\right)$ & 0.893 & 0.206 & 0.750 & 1.064 \\
\hline History of smoking & 0.285 & 0.490 & 0.008 & 10.040 \\
\hline
\end{tabular}

OR odds ratio, $C I$ confidence interval, $A S A$ American Society of Anesthesiology, $B M I$ body mass index 


\section{DISCUSSION}

According to the study data, the application of simultaneous panniculectomy in ventral hernia repair does not increase the postoperative complication rates but only extends the hospitalization time. Similar postoperative complication rates in both groups suggested that other factors might be effective on the extension of the hospitalization. Some studies have suggested that daily activity disorders already existing in patients who have pannus before the operation had a negative effect on the postoperative healing process ${ }^{5,11}$. A late mobilization leads to an increased hospitalization period in the recovery process. However, in the regression analysis in the study, it was determined that the increase in hernia defect was an independent variable that affects the extension of the duration of the defect. According to the data in the present study, in patients in which ventral hernia repair and panniculectomy were performed simultaneously, the hernia defect area was approximately 6.25-fold larger of those who underwent only the ventral hernia repair $\left(225 \mathrm{~cm}^{2}\right.$ vs $36 \mathrm{~cm}^{2}$ ). In these patients, the use of a wider dissection and a large mesh should cause a more severe inflammatory response, and it can lead to the extension of the recovery of mobilization and recovery process ${ }^{12,13}$. Another important issue associated with hernia defect is the risk of postoperative wound complication due to a large dissection area and large mesh use. Although it was suggested that wound complications will increase in these patients, a certain cut-off $\mathrm{cm}^{2}$ (hernia defect area) was not described ${ }^{14}$.

It has been known that both operations (ventral hernia and panniculectomy) have the potential for wound complications. In onlay ventral hernia (the method used in this study) the wound complication rate was $16.9 \%$, while it was $7 \%$ in panniculectomy ${ }^{15,16}$. Therefore, a simultaneous procedure in a single session has been a cause of concern. In the case of panniculectomy in ventral hernia repairs in the literature, some studies have indicated that wound complications increased up to five-fold whereas some have reported that there were no significant differences in terms of an increase in

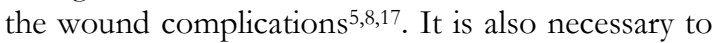
consider the heterogeneity of ventral hernia patients. These patients can be found in a wide range from those who underwent a simple umbilical hernia to wide ventral hernias with multiple incisional operations. In addition, there may be quite different surgical techniques such as how the mesh is placed (onlay, inlay, sublay), mesh type and whether or not compartment separation is performed ${ }^{15,18}$. Also, the pannus tissue volume of the panniculectomy shows significant differences. In the present study, the wound complication rates were $28.6 \%$ and $33.3 \%$ in both groups, respectively, and there were no significant differences. These values were also in agreement with the literature data 5,7,14,17,19. Despite the disadvantage of the broad dissection in the panniculectomy group, it may have balanced these disadvantages by reconstruction with the excision of the pannus with a relatively weak circulation ${ }^{19-21}$. The long-term complications such as recurrence of hernia in simultaneous ventral hernia operations with panniculectomy procedures have been another concern. In a study where a propensity score match consisting of 624 patients (age, hernia defect area, subcutaneous fat volume, smoking, diabetes) pairing was performed, similar recurrence rates were found in an average of a 28 -week-follow-up (respectively, $8 \%, 9 \%)^{21}$. In another retrospective multi-centered study, patients with ventral hernia and panniculectomy ( $\mathrm{n}=1013$ ) were compared with patients $(n=18328)$ only with ventral hernia repair. Higher early complication rates were determined in the simultaneous ventral hernia and panniculectomy group (29.3\% vs $20.7 \%$; OR 2.34 ), however, it had lower hernia recurrence rates. $(7.9 \%$ vs $11.3 \%$; OR: $0.65)^{22}$. In the present study, the intergroup hernia recurrence rates were $14.3 \%$ and $11.1 \%$ recurrence (respectively, group 1 and group 2), and no significant differences were determined $(p=0.84)$.

In all patients with ventral hernia and pannus, the quality of life is adversely affected. In a retrospective study, the effects of sole ventral hernia repair, simultaneous hernia repair, and panniculectomy were investigated on the quality of life and it was found that the quality of life increased in both groups ${ }^{23}$. In a different study in which the number of patients was higher, mesh sensation, pain, daily activity limitation, and overall quality of life was evaluated postoperatively on week 2 , month 6 , and month 12 following the procedures. There were no significant differences between the groups other than a significant limitation in daily activity in the first year ${ }^{24}$. The most important limitation of the present study was that these surgeries had not been investigated in terms of their effects on the quality of life. The fact that the present study was a retrospective study consisting of few patients, the potential bias caused by high heterogeneity of ventral hernia diagnosis and 
the treatment comprised the other limitations. However, the strong sides of the study include the fact that the procedures were performed by the same surgical team and this reflected the experience of a secondary state hospital.

In conclusion, simultaneous panniculectomy applications in ventral hernia repairs do not increase the rate of complications and hernia recurence. A simultaneous operation can be safely applied to patients who want to "eliminate" their both problems in a single session.

Yazar Katkıları: Çalışma konsepti/Tasarımı: SK; Veri toplama: EH; Veri analizi ve yorumlama: SK; Yazı taslağı: SK, EH; İçeriğin eleştirel incelenmesi: SK; Son onay ve sorumluluk: SK, EH; Teknik ve malzeme desteği: -; Süpervizyon: SK; Fon sağlama (mevcut ise): yok.

Etik Onay: Bu çalışma için Yozgat Bozok Üniversitesi Klinik Araştrımalar Etik Kurulundan (No: 2017-KAEK-189_2021.02.10_12). Araştırma kodu ile etik onay alınmıştır.

Hakem Değerlendirmesi: Dıș bağımsız.

Çıkar Çatışması: Yazarlar çıkar çatışması beyan etmemişlerdir.

Finansal Destek: Yazarlar finansal destek beyan etmemişlerdir.

Author Contributions: Concept/Design : SK; Data acquisition: EH; Data analysis and interpretation: SK; Drafting manuscript: SK, EH, Critical revision of manuscript: SK; Final approval and accountability: SK, EH; Technical or material support: -; Supervision: SK; Securing funding (if available): $\mathrm{n} / \mathrm{a}$.

Ethical Approval: For this study, Yozgat Bozok University Clinical Research Ethics Committee (No: 2017-KAEK-189_2021.02.10_12). Ethical approval was obtained with the research code.

Peer-review: Externally peer-reviewed.

Conflict of Interest: Authors declared no conflict of interest.

Financial Disclosure: Authors declared no financial support

\section{REFERENCES}

1. Schlosser KA, Arnold MR, Otero J, Prasad T, Lincourt A, Colavita PD et al. Deciding on optimal approach for ventral hernia repair: laparoscopic or open. J Am Coll Surg. 2019;228:54-65.

2. Olavarria OA, Bernardi K, Shah SK, Wilson TD, Wei $S$, Pedroza $C$ et al. Robotic versus laparoscopic ventral hernia repair: multicentre, blinded randomized controlled trial. BMJ. 2020;370:m2457.

3. Ozkan H, Acar A, Gökce AH. Shall we use a mesh in every patient undergoing repair surgery for an umbilical hernia? a prospective study. Cukurova Medical Journal. 2019;44:169-75.

4. 4. Cooper JM, Paige KT, Beshlian KM, Downey DL, Thirlby RC. Abdominal panniculectomies: high patient satisfaction despite significant complication rates. Ann Plast Surg. 2008;61:188-96.

5. Zemlyak AY, Colavita PD, El Djouzi S, Walters AL, Hammond L, Hammond B et al. Comparative study of wound complications: isolated panniculectomy versus panniculectomy combined with ventral hernia repair. J Surg Res. 2012;177:387-91.

6. Fischer JP, Basta MN, Wink JD, Wes AM, Kovach SJ. Optimizing patient selection in ventral hernia repair with concurrent panniculectomy: an analysis of 1974 patients from the ACS-NSQIP datasets. J Plast Reconstr Aesthet Surg. 2014;67:1532-40.

7. Saxe A, Schwartz S, Gallardo L, Yassa E, Alghanem A. Simultaneous panniculectomy and ventral hernia repair following weight reduction after gastric bypass surgery: is it safe? Obes Surg. 2008;18:192-5.

8. Warren JA, Epps M, Debrux C, Fowler III JL, Ewing JA, Cobb WS, et al. Surgical site occurrences of simultaneous panniculectomy and incisional hernia repair. Am Surg. 2015;81:764-9.

9. Muysoms FE, Miserez M, Berrevoet F, Campanelli G, Champault GG, Chelala E et al. Classification of primary and incisional abdominal wall hernias. Hernia. 2009;13:407-14.

10. Dindo D, Demartines N, Clavien PA. Classification of surgical complications: a new proposal with evaluation in a cohort of 6336 patients and results of a survey. Ann Surg. 2004;240:205-13.

11. Gurunluoglu R, Williams SA, Johnson JL. A classification system in the massive weight loss patient based on skin lesions and activity of daily living. Eplasty. 2012;12:e12.

12. Kokotovic D, Burcharth J, Helgstrand F, Gögenur I. Systemic inflammatory response after hernia repair: a systematic review. Langenbecks Arch Surg. 2017;402:1023-37.

13. Jess P, Schultz K, Bendtzen K, Nielsen OH. Systemic inflammatory responses during laparoscopic and open inguinal hernia repair: a randomised prospective study. Eur J Surg. 2000;166:540-4.

14. McNichols CHL, Diaconu S, Liang Y, Ikheloa E, Kumar S, Kumar S et al. Outcomes of ventral hernia repair with concomitant panniculectomy. Ann Plast Surg. 2018;80:391-4.

15. Holihan JL, Nguyen DH, Nguyen MT, Mo J, Kao LS, Liang MK. Mesh location in open ventral hernia repair: a systematic review and network meta-analysis. World J Surg. 2016;40:89-99.

16. Cammarata MJ, Kantar RS, Rifkin WJ, Greenfield JA, Levine JP, Ceradini DJ. Advanced age is a risk factor for complications following abdominal panniculectomy. Obes Surg. 2019;29:426-33.

17. Harth KC, Blatnik JA, Rosen MJ. Optimum repair for massive ventral hernias in the morbidly obese patient-is panniculectomy helpful? Am J Surg. 2011;201:396400.

18. Maloney SR, Schlosser KA, Prasad T, Colavita PD, Kercher KW, Augenstein VA et al. The impact of component separation technique versus no component separation technique on complications and quality of life in the repair of large ventral hernias. Surg Endosc. 2020;34:981-7.

19. Giordano S, Garvey PB, Baumann DP, Liu J, Butler CE. Concomitant panniculectomy affects wound morbidity but not hernia recurrence rates in abdominal wall reconstruction: a propensity score analysis. Plast Reconstr Surg. 2017;140:1263-73. 
20. Simon S, Thaller SR, Nathan N. Abdominoplasty combined with additional surgery: a safety issue. Aesthet Surg J. 2006;26:413-6.

21. Janis JE, Khansa I. Evidence-based abdominal wall reconstruction: The maxi-mini approach. Plast Reconstr Surg. 2015;136:1312-23.

22. Shubinets V, Fox JP, Tecce MG, Mirzabeigi MN, Lanni MA, Kelz RR et al. Concurrent panniculectomy in the obese ventral hernia patient: assessment of short-term complications, hernia recurrence, and healthcare utilization. J Plast Reconstr Aesthet Surg. 2017;70:759-67.
23. Hutchison CE, Rhemtulla IA, Mauch JT, Broach RB, Enriquez FA, Hernandez JA et al. Cutting through the fat: a retrospective analysis of clinical outcomes, cost, and quality of life with the addition of panniculectomy to ventral hernia repair in overweight patients. Hernia. 2019;23:969-77.

24. Elhage SA, Marturano MN, Deerenberg EB, Shao JM, Prasad T, Colavita PD et al. Impact of panniculectomy in complex abdominal wall reconstruction: a propensity matched analysis in 624 patients. Surg Endosc. 2020; doi: 10.1007/s00464-020-08011-7. 